\title{
Microstructure, Hardness, and Tensile Properties of Vacuum Carburizing Gear Steel
}

\author{
Wu Chen ${ }^{1,2}$, Xiaofei He ${ }^{3}$, Wenchao Yu ${ }^{3}$, Maoqiu Wang ${ }^{3, *}$ and Kefu Yao ${ }^{1}$ \\ 1 School of Materials Science and Engineering, Tsinghua University, Beijing 100084, China; \\ chenwu15@mails.tsinghua.edu.cn (W.C.); kfyao@mail.tsinghua.edu.cn (K.Y.) \\ 2 NCS Testing Technology Co., Ltd., Beijing 100081, China \\ 3 Institute of Special Steel, Central Iron and Steel Research Institute, Beijing 100081, China; \\ hexiaofei@nercast.com (X.H.); yuwenchao@nercast.com (W.Y.) \\ * Correspondence: maoqiuwang@hotmail.com; Tel.: +86-10-62186791
}

check for

updates

Citation: Chen, W.; He, X.; Yu, W.; Wang, M.; Yao, K. Microstructure, Hardness, and Tensile Properties of Vacuum Carburizing Gear Steel. Metals 2021, 11, 300. https:// doi.org/10.3390/met11020300

Academic Editor: Marcello Cabibbo Received: 21 January 2021

Accepted: 3 February 2021

Published: 9 February 2021

Publisher's Note: MDPI stays neutral with regard to jurisdictional claims in published maps and institutional affiliations.

Copyright: (c) 2021 by the authors. Licensee MDPI, Basel, Switzerland. This article is an open access article distributed under the terms and conditions of the Creative Commons Attribution (CC BY) license (https:// creativecommons.org/licenses/by/ $4.0 /)$.

\begin{abstract}
We investigated the effects of the austenitizing temperature on the microstructure, hardness, and tensile properties of case-carburized steel after vacuum carburization at $930{ }^{\circ} \mathrm{C}$ and then reaustenitization at $820-900{ }^{\circ} \mathrm{C}$ followed by oil quenching and tempering. The results show that fractures occurred early with the increase in the austenitizing temperature, although all the carburized specimens showed a similar case hardness of $800 \mathrm{HV}_{0.2}$ and case depth of $1.2 \mathrm{~mm}$. The highest fracture stress of $1919 \mathrm{MPa}$ was obtained for the experimental steel when the austenitizing temperature was $840{ }^{\circ} \mathrm{C}$ due to its fine microstructure and relatively high percentage of retained austenite transformed into martensite during the tensile tests. We also found that the stress-strain behavior of casecarburized specimens could be described by the area-weighted curves of the carburized case and the core in combination. The strain hardening exponent was about 0.4 and did not vary with the increase in the austenitizing temperature. We concluded that the optimum austenitizing temperature was around $840{ }^{\circ} \mathrm{C}$ for the experimental steel.
\end{abstract}

Keywords: gear steel; vacuum carburizing; retained austenite; tensile test; fracture

\section{Introduction}

Gears are typically carburized to have very high hardness and wear resistance in the case and excellent toughness in the core. The most widely used carburizing method is gas carburizing [1]. However, this has been gradually replaced by vacuum carburizing due to the advantages of the latter, such as less near-surface intergranular oxidation and less quenching distortion [2]. As vacuum carburizing might result in coarse grain sizes when a high carburizing temperature above $930^{\circ} \mathrm{C}$ is used, re-austenitizing and quenching are required instead of direct quenching after carburizing. Re-austenitizing and quenching after vacuum carburizing at around $930{ }^{\circ} \mathrm{C}$ are also used in certain cases, in particular for heavy-duty gears. However, the effect of the re-austenitizing temperature on the microstructure and mechanical properties of vacuum-carburized specimens has not been fully clarified, and the optimum re-austenitizing temperature should be determined for particular situations.

Due to the complex microstructure in the carburized case [1], which is typically composed of martensite, retained austenite, and carbides, the mechanical properties of vacuum-carburized specimens can vary largely and be influenced by many factors [3-5]. The mechanical properties of carburized specimens are usually characterized in terms of the hardness and fatigue resistance. However, hardness tests are too simple and fatigue tests are too complicated for carburized specimens. Tensile tests of carburized specimens are a good compromise for considering both aspects. Thus, it is necessary to study the tensile behavior of carburized specimens. 
Previous studies showed some contradictory results regarding the tensile properties of carburized steels [6-12]. Luther and Williams compared the tensile properties of carburized and un-carburized low carbon mild steel and found an increase in tensile strength by $45 \%$ after carburizing and slant fracture instead of cup and cone [6]. Krauss observed the microstructure and fracture of carburized 8620 steel and found the transition of the fracture mode from microvoid coalescence (MVC) around carbides to transgranular fracture [7]. Furukawa and coworkers found that re-quenching after carburizing could improve both the strength and ductility of carburized specimens [8]. Li et al. investigated the influence of heat treatment after carburizing on the strength of carburized 18Cr2Ni4WA steel and found that the tensile strength was about 1200-1300 MPa and the fracture mode was intergranular [9].

Ergoan and Tekeli investigated the tensile strength of carburized 8620 steel and found a much lower tensile strength of $1005 \mathrm{MPa}$ with a fracture surface of the cleavage facet [10]. Murai attributed the intergranular fracture of carburized steel to carbide formation at the austenite grain boundaries [11]. Recently, Yu and coworkers investigated the influence of carbide formation on the tensile and fatigue properties of carburized steels and found that the fine carbides acted as resistance sites against crack propagation and improved the mechanical properties, while the networked carbides deteriorated the properties [12]. Other works focused on the effect of retained austenite in carburized steels and found that it could transform into martensite during stressing or after cryogenic treatment [13-18]. It is still controversial whether the tensile properties of carburized specimens can reflect the mechanical properties of gear steel since the carburized case has complex microstructural constitutes.

The aim of this work is to study the tensile behavior of carburized specimens of gear steel after vacuum carburization and re-austenitization at different temperatures and to investigate the effect of the austenitizing temperature on the microstructure and tensile properties of vacuum-carburized gear steel. In the experimental part, the details including the experimental steel, processes, and methods will be described. In the results and discussion, experimental results including the microstructure, hardness, and tensile properties will be given and discussed. Based on the results, our conclusions will finally be drawn.

\section{Experimental}

Case-hardening steel $16 \mathrm{CrMnH}$, which is specified in the Chinese National Standard GB/T 5216-2020, was used in this work. The experimental steel was industrially produced by the method of electric furnace melting, ladle refining, and vacuum degassing, followed by continuously casting and hot rolling. This was provided in the form of hot-rolled bars, $80 \mathrm{~mm}$ in diameter. The chemical compositions of the experimental steel are listed in Table 1 and were tested according to the serial Chinese National Standards numbered GB/T 223.

Table 1. Chemical composition of the experimental steel (wt.\%).

\begin{tabular}{ccccccc}
\hline $\mathbf{C}$ & $\mathbf{S i}$ & $\mathbf{M n}$ & $\mathbf{C r}$ & $\mathbf{P}$ & $\mathbf{S}$ & $\mathbf{F e}$ \\
\hline 0.16 & 0.08 & 1.22 & 1.22 & 0.014 & 0.024 & Bal. \\
\hline
\end{tabular}

Specimens with the size of $14 \mathrm{~mm}$ in diameter and $162 \mathrm{~mm}$ in length, as shown in Figure 1, were machined from the $1 / 2$ radius position of the hot-rolled bars. Carburizing of the specimens was carried out in a WZST-45 type vacuum carburizing furnace, made by the Beijing Institute of Mechatronics (BIM, Beijing, China). The carburizing process and heat treatment process are shown in Figure 2. Carburizing was held first at $930{ }^{\circ} \mathrm{C}$ for $7 \mathrm{~h}$ at the expected equivalent carbon potential of $1.1 \%$, and then at $930{ }^{\circ} \mathrm{C}$ for $1 \mathrm{~h}$ at the expected equivalent carbon potential of $0.85 \%$, followed by air cooling to room temperature. The specimens were then re-heated to $820-900{ }^{\circ} \mathrm{C}$ in an air furnace (BIM, Beijing, China) for austenitizing for $1 \mathrm{~h}$, followed by oil quenching and tempering at $180{ }^{\circ} \mathrm{C}$ for $2 \mathrm{~h}$. After heat treatment, the specimens were finished with polishing before the tensile tests. 


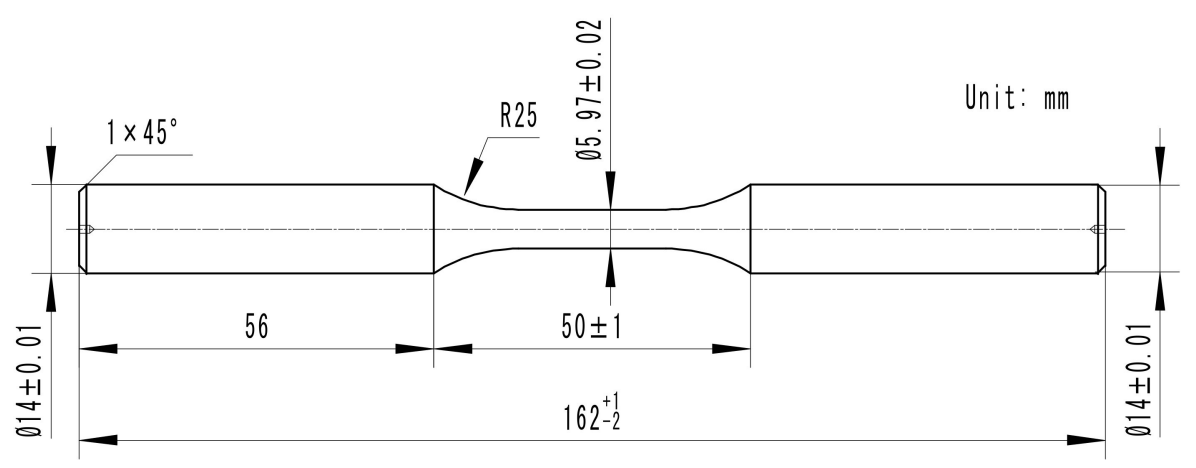

Figure 1. The shape and dimensions of the specimens for the tensile tests.

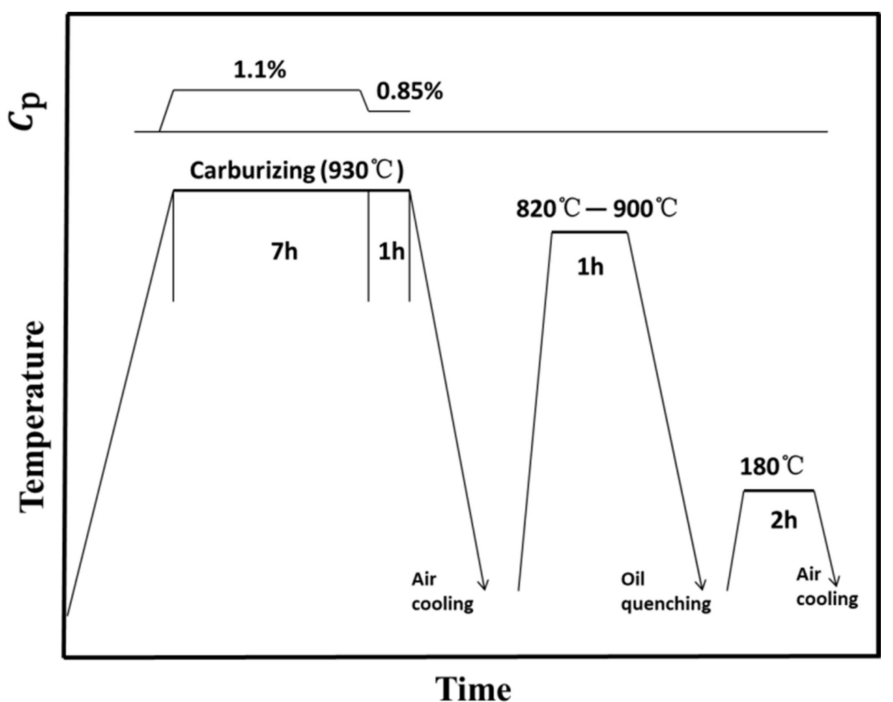

Figure 2. Schematic illustration of the vacuum carburizing and heat treatment processes of the experimental steel, where $C_{p}$ shows the expected equivalent carbon potential during the carburizing process.

The microstructure in the carburized case and the matrix of the specimens, after crosssection machining, polishing, and etching in a 3\% Nital solution, was observed on an optical microscope and a JSM-6400 type (JOEL, Tokyo, Japan) scanning electron microscope (SEM), operating at $15 \mathrm{kV}$. Retained austenite in the carburized case of the specimens was also measured by means of X-ray diffraction (XRD) on a BRUKER D8 ADVANCE $X$ diffractor (BRUKER, Karlsruhe, Germany) at $35 \mathrm{kV}$ with a $40 \mathrm{~mA}$ current using Co-Ka radiation. The retained austenite amount was calculated according to the data collected containing (111), (200), (220), and (311) gamma and the (110), (200), and (211) alpha reflections.

The in-depth Vickers hardness distribution from the carburized case was obtained on a TUKON 2500-6 type (TUKON, Norwood, Massachusetts, USA) Vickers hardness tester with a load of $200 \mathrm{gf}(1.96 \mathrm{~N})$ for a holding time of $10 \mathrm{~s}$. Each reported value of Vickers hardness was averaged one for five readings. The case-hardening depth was calculated from the results of the Vickers hardness distribution with the critical value of $550 \mathrm{HV}_{0.2}$ according to the ISO 18203 standard. Using the specimens as shown in Figure 1, tensile tests at room temperature were performed on the machine of MTS 810 type (MTS, Minneapolis, Minnesota, USA) at a strain rate of $2.5 \times 10^{-3}-2.5 \times 10^{-4} \mathrm{~s}^{-1}$ according to the Chinese National Standard GB/T 228.1-2010. For each austenitizing temperature, three specimens were tested and the results were averaged.

After the tensile tests, the fracture surfaces of the specimens were observed on a JSM-6400 type (JOEL, Tokyo, Japan) scanning electron microscope (SEM), operating at $15 \mathrm{kV}$. 


\section{Result and Discussion}

\subsection{Microstructure}

Figure 3 shows the SEM micrographs in the carburized case of the experimental steel after carburization and austenitization at $820-900{ }^{\circ} \mathrm{C}$, followed by oil quenching and tempering at $180^{\circ} \mathrm{C}$ for $2 \mathrm{~h}$. The carburized case consisted of plate martensite, carbides, and retained austenite, which are typical for high-carbon steels. When the austenitizing temperature was $820^{\circ} \mathrm{C}$, network carbides were distributed along with the prior austenite grain boundaries, as shown in Figure 3a. When the austenitizing temperature was $840^{\circ} \mathrm{C}$, network carbides were occasionally found along with prior austenite grain boundaries, as shown in Figure $3 \mathrm{~b}$. When the austenitizing temperature was $860^{\circ} \mathrm{C}$ and above, blocky retained austenite could be distinguished, as shown in Figure $3 c, d$. Thus, the network carbides gradually dissolved and the fraction of retained austenite increased with the increase in the austenitizing temperature from 820 to $860^{\circ} \mathrm{C}$.

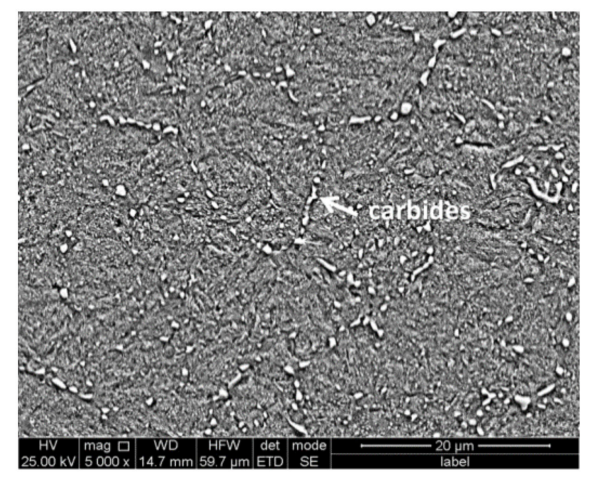

(a)

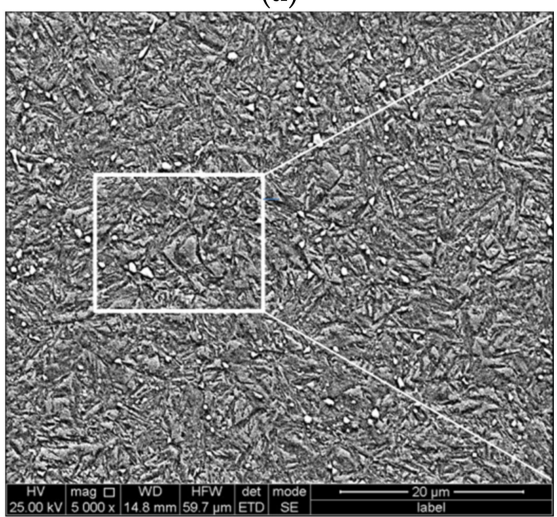

(c)

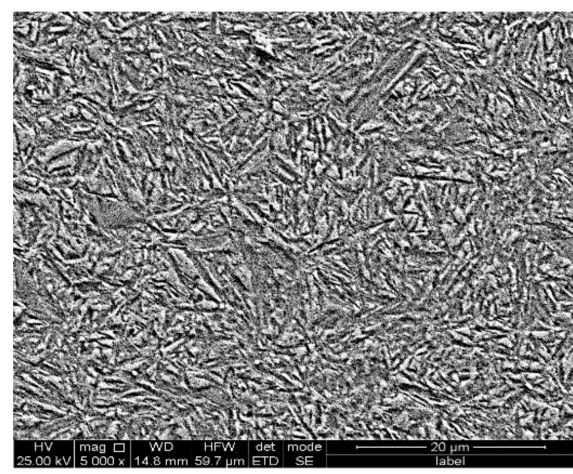

(e)

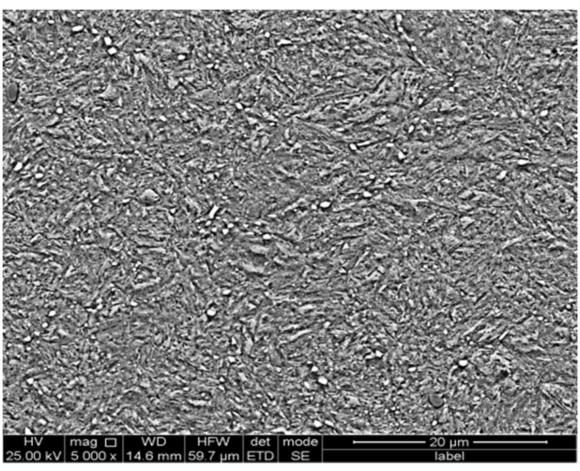

(b)

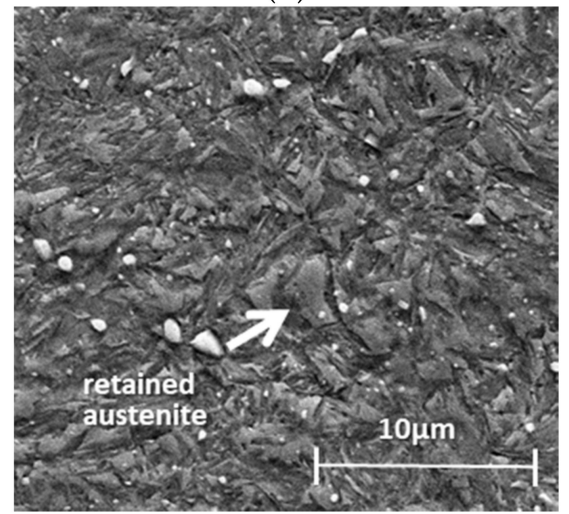

(d)

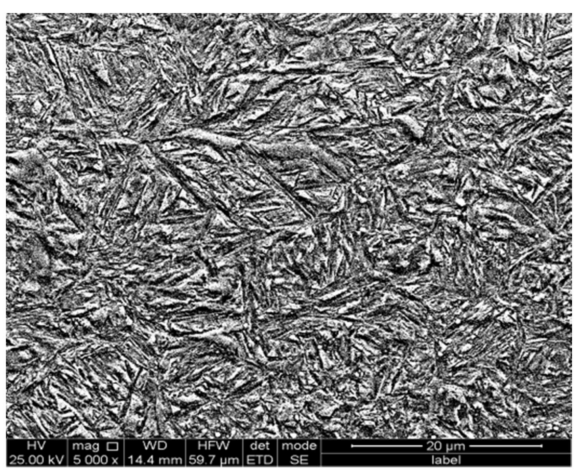

(f)

Figure 3. Scanning electron microscope (SEM) micrographs showing the carburized case of the specimens re-austenitized at (a) $820^{\circ} \mathrm{C}$, (b) $840{ }^{\circ} \mathrm{C}$, (c) and (d) $860^{\circ} \mathrm{C}$, (e) $880{ }^{\circ} \mathrm{C}$, and (f) $900{ }^{\circ} \mathrm{C}$. 
As listed in Table 2, the weight percentages of retained austenite were measured by XRD diffraction to be $18-30 \%$ for the specimens austenitized at different temperatures. At the same time, the microstructure did not coarsen evidently with the increase in the austenitizing temperature from 820 to $860^{\circ} \mathrm{C}$, with the average prior austenite grain sizes being about $5-7 \mu \mathrm{m}$. However, when the austenitizing temperature was higher than $860^{\circ} \mathrm{C}$, the microstructure did coarsen, with the average prior austenite grain sizes being about 13-17 $\mu \mathrm{m}$, as shown in Figure 3e,f. Thus, the experimental steel showed a relatively fine prior austenite grain size, as the highest austenitizing temperature was no higher than $900{ }^{\circ} \mathrm{C}$.

Table 2. Microstructural constituents in the near-surface carburized case of the steel.

\begin{tabular}{|c|c|c|c|c|c|}
\hline $\begin{array}{c}\text { Austenitizing } \\
\text { Temperature, }\left({ }^{\circ} \mathrm{C}\right)\end{array}$ & $\begin{array}{c}\text { Retained } \\
\text { Austenite, } V_{\gamma}(\%)\end{array}$ & $\begin{array}{c}\text { Martensite Start } \\
\text { Temperature, } M_{\mathrm{s}}\left({ }^{\circ} \mathrm{C}\right)\end{array}$ & $\begin{array}{c}\text { C Content in } \gamma \text { before } \\
\text { Oil Quenching, }(\%)\end{array}$ & $\begin{array}{l}\text { Undissolved } \\
\text { Carbides, (\%) }\end{array}$ & $\alpha^{\prime},(\%)$ \\
\hline 820 & 18 & 177 & 0.73 & 2.0 & 80.0 \\
\hline 840 & 25 & 143 & 0.81 & 0.7 & 74.3 \\
\hline 860 & 30 & 130 & 0.84 & 0.2 & 69.8 \\
\hline 880 & 23 & 151 & 0.79 & - & 77.0 \\
\hline 900 & 21 & 164 & 0.76 & - & 79.0 \\
\hline
\end{tabular}

During carburizing, carbon can diffuse into the specimens from the surface, resulting in a carbon gradient distribution in the near-surface case. Since the carbon potential was $0.85 \%$ at the later stage of the carburzing process, we assumed that the average carbon content in the specimen surface was around $0.85 \%$ after carburizng and air cooling, although much of the carbon was in carbides. After austenitizsing at 820,840 , and $860^{\circ} \mathrm{C}$, some of the carbides were dissolved into austenite, with the carbon content in the austenite depending on the austenitizing temperature. During oil quenching, some of the austenite transformed into martensite, while some was retained as austenite. Thus, the content of retained austenite in the specimen was dependent on the situation of austenite before oil quenching.

According to Magee's equation [19], the content of retained austenite $\left(V_{\gamma}\right)$ in the as-quenched specimens can be calculated as follows:

$$
V_{\gamma}=\exp \left[-\alpha\left(M_{\mathrm{s}}-T_{\mathrm{q}}\right)\right]
$$

where $M_{\mathrm{s}}$ is the starting temperarure of martensite transformation of the austenite before quenching, $T_{\mathrm{q}}$ is the temperatrue of the quenching, and $\alpha$ is a constant with the value of $1.10 \times 10^{-2}$. Since the contents of retained austenite in the specimens austenitized at $820,840,860,880$, and $900{ }^{\circ} \mathrm{C}$ were measured to be $18 \%, 25 \%, 30 \%, 23 \%$, and $21 \%$, the $M_{\mathrm{s}}$ temperatures were calculated according to Equation (2) to be 177, 143, 130, 151, and $164{ }^{\circ} \mathrm{C}$, respectively. The carbon contents in austenite before oil quenching were calculated to be $0.73 \%, 0.81 \%, 0.84 \%, 0.79 \%$, and $0.76 \%$, respectively, according to the following equation [20]:

$$
M_{\mathrm{S}}\left({ }^{\circ} \mathrm{C}\right)=539-423 \mathrm{C}-30.4 \mathrm{Mn}-17.7 \mathrm{Ni}-12.1 \mathrm{Cr}-7.5 \mathrm{Mo}
$$

Considering the carbon balance between undissolved carbides and austenite at the austenitizing temperature, the contents of undissolved carbides and those of the quenched martensite can be also calculated. The calculated results are listed in Table 2, and the undissolved carbides decreased from $2 \%$ to $0.7 \%$ when the austenitizing temperature was increased from 820 to $840^{\circ} \mathrm{C}$, which is consistent with the micrographs in Figure 3. With the increase in the austenitizing temperature from 820 to $860{ }^{\circ} \mathrm{C}$, the content of martensite in the near-surface carburized case was decreased from $80 \%$ to approximately $70 \%$. According to theoretical calculations based on the iron-carbon phase diagram, the absolute dissolution of carbides could occur only at temperatures higher than $880^{\circ} \mathrm{C}$. This indicates that more austenite was retained at a higher austenitizing temperature. Because of the increased 
number of carbides dissolved into austenite, the carbon content in the austenite is higher, and the $M_{\mathrm{S}}$ temperature is lower. It was easy to form retained austenite.

\subsection{In-Depth Hardness Distribution}

Figure 4 shows the in-depth distribution of the Vickers hardness of the experimental steel after carburizing, austenitizing at different temperatures, and tempering. There were three regions according to the hardness variations. In the region within the distance of $0.6 \mathrm{~mm}$ from the surface, the hardness was very high, with a value of around $750-800 \mathrm{HV}_{0.2}$, and it varied slightly within $50 \mathrm{HV}_{0.2}$. In the region with the depth distance from 0.6 to $1.5 \mathrm{~mm}$ ( or $2.0 \mathrm{~mm}$ for the specimen austenitized at $820^{\circ} \mathrm{C}$ ), the hardness decreased linearly with the increasing distance. When the depth distance was more than $1.5 \mathrm{~mm}$ (or $2.0 \mathrm{~mm}$ ), the hardness decreased slowly and finally tended to be constant, which was in the core matrix region. If a critical value of $550 \mathrm{HV}_{0.2}$ was assumed, the carburized effective case depth was measured to be around $1.2 \mathrm{~mm}$ for all the specimens.

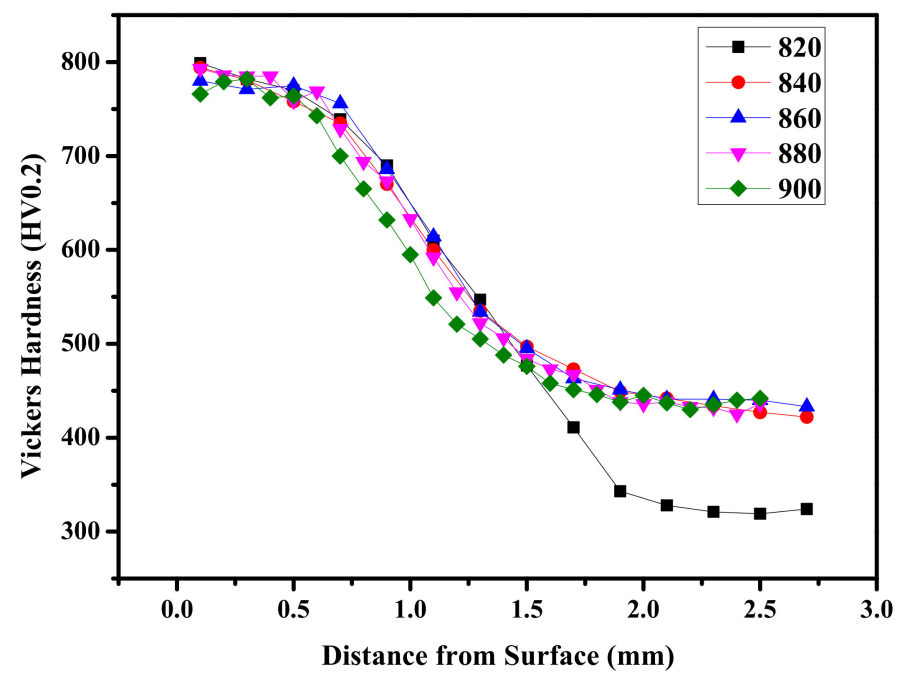

Figure 4. The in-depth hardness distribution of the specimens austenitized at different temperatures, as indicated by the serial number.

Comparing the in-depth hardness distributions of the specimens austenitized at different temperatures, we can see that the hardness in the carburized case (within $1.2 \mathrm{~mm}$ from the surface) varied very slightly with the austenitizing temperature. If we look carefully at the hardness variation in the near-surface region, we can find a slightly higher hardness of the specimen austenitized at $820{ }^{\circ} \mathrm{C}$ in comparison with the specimens austenitized at other temperatures. This can be attributed to the relatively higher content of martensite and lower content of retained austenite in the specimen austenitized at $820^{\circ} \mathrm{C}$, as listed in Table 2.

It can also be seen from Figure 5 that the core matrix hardness of the specimen austenitized at $820^{\circ} \mathrm{C}$ was clearly lower than those of the specimens austenitized at other temperatures. As shown in Figure 5a, the microstructure in the core matrix of the specimen austenitized at $820^{\circ} \mathrm{C}$ consisted of soft ferrite, pearlite, and martensite, which was different from those of martensite and bainite for the specimens austenitized at other temperatures, as shown in Figure 5b-e. The fully austenitizing temperature named the Ac3 temperature of the experimental steel with the chemical compositions listed in Table 1 was calculated to be around $830^{\circ} \mathrm{C}$ according to the following equation [20]:

$$
A_{\mathrm{C} 3}\left({ }^{\circ} \mathrm{C}\right)=910-203 \mathrm{C}^{1 / 2}+44.7 \mathrm{Si}-15.2 \mathrm{Ni}+31.5 \mathrm{Mo}+104 \mathrm{~V}+13.1 \mathrm{~W} .
$$




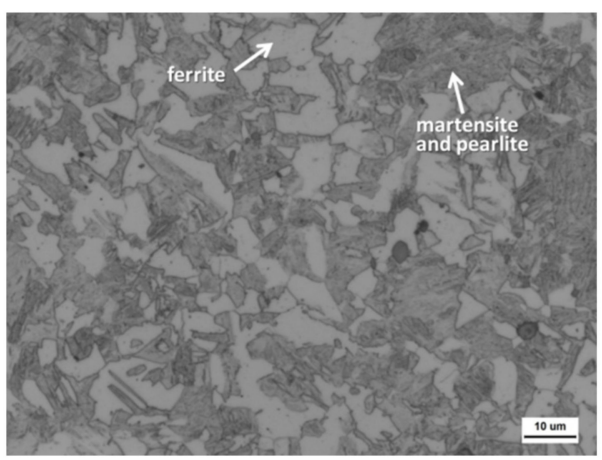

(a)

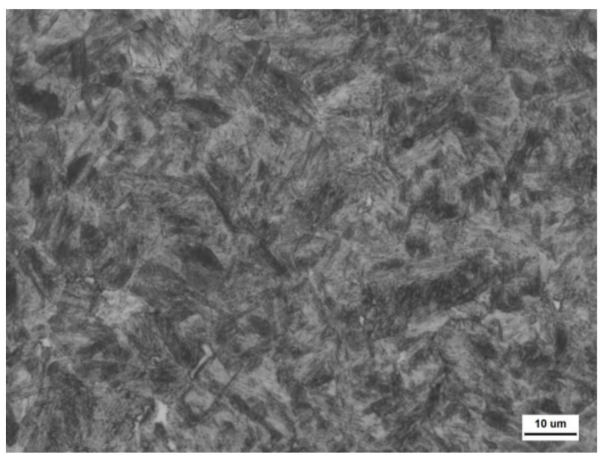

(c)

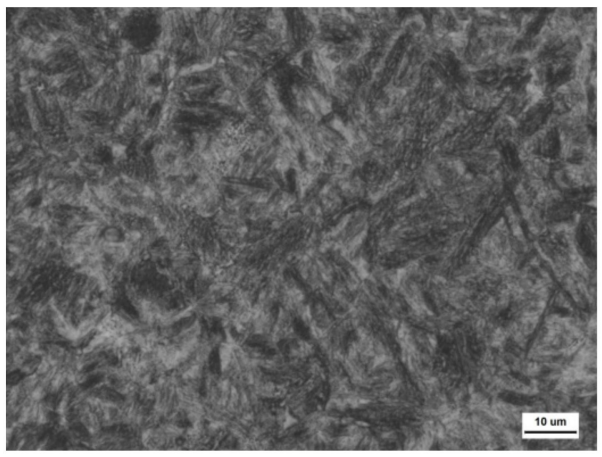

(e)

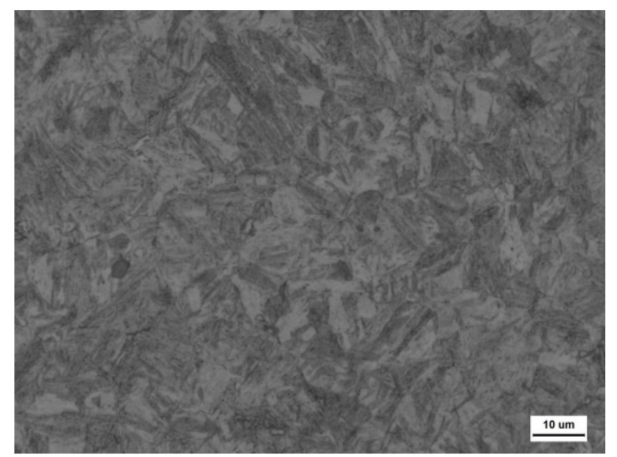

(b)

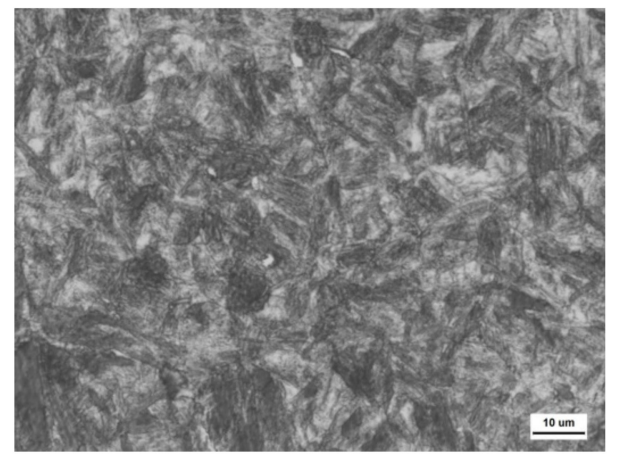

(d)

Figure 5. Optical micrographs showing the microstructure in the core matrix of the specimens austenitized at (a) $820^{\circ} \mathrm{C}$, (b) $840{ }^{\circ} \mathrm{C}$, (c) $860^{\circ} \mathrm{C}$, (d) $880^{\circ} \mathrm{C}$, and (e) $900{ }^{\circ} \mathrm{C}$.

This indicates that the austenitizing was not fully complete at the temperature of $820{ }^{\circ} \mathrm{C}$. Thus, the existence of ferrite in the core matrix of the specimen austenitized at $820^{\circ} \mathrm{C}$ resulted in a much lower hardness in comparison with those of the specimens austenitized at other temperatures.

\subsection{Tensile Properties}

Figure 6 shows the tensile stress-strain curves of the experimental steel after carburizing, austenitizing at different temperatures, and tempering. All the carburized specimens show early fracture, although the fracture stress is relatively high. Since the carburized specimens had a gradient carbon content, the microstructure and hardness distribution along the depth and the tensile stress-strain curves were different from both high carbon steels with high brittleness and low carbon steels with good ductility. As shown in Figure 6, the engineering stress-strain curves and true stress-strain curves can be divided into two stages: the first was the elastic stage and the second was the plastic stage. In the elastic stage, the specimens extended uniformly and there was no evident difference among the specimens austenitized at different temperatures. In the plastic stage, the specimens 
showed strain hardening, and all the specimens austenitized at different temperatures showed a similar hardening effect with a strain hardening exponent of approximately 0.4 . The elastic-plastic behavior of the experimental steel did not vary with the austenitizing temperature.

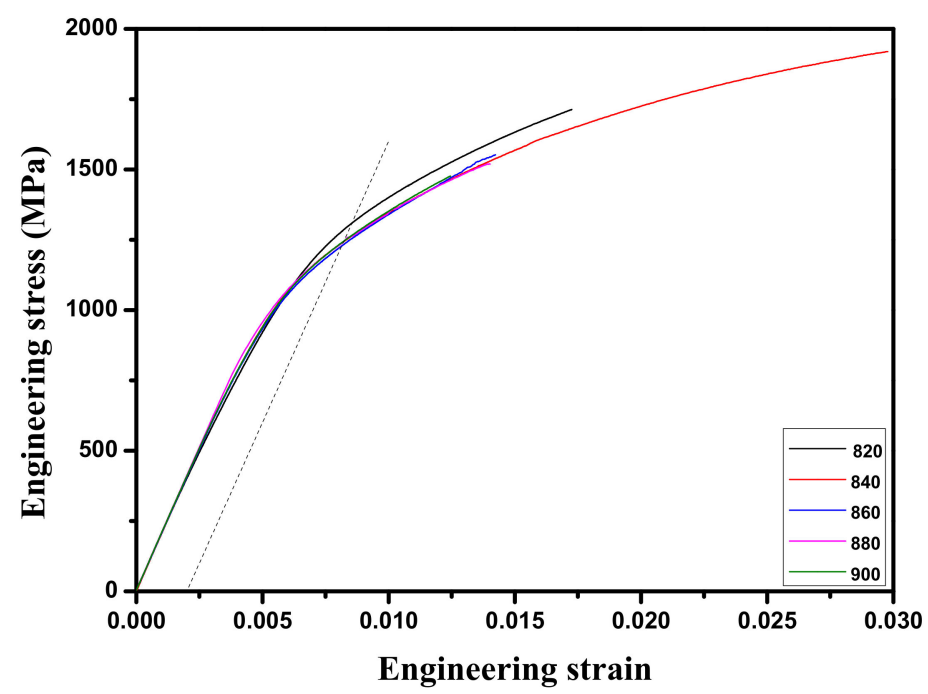

Figure 6. Tensile stress-strain curves of the specimens austenitized at different temperatures as indicated by the serial number.

Table 3 shows the parameters obtained by the tensile tests on the carburized specimens with different austentizing temperatures. The yield stresses and fracture stresses showed a decreasing trend with the increase in the austenitizing temperature, especially at the relatively low austenitizing temperatures. When the austenitizing temperature was $820^{\circ} \mathrm{C}$, the yield stress and the fracture stress were 1322 and $1713 \mathrm{MPa}$, respectively. When the austenitizing temperature was increased to $840^{\circ} \mathrm{C}$, the yield stress and the fracture stress were changed to 1249 and $1919 \mathrm{MPa}$, respectively. A further increase in the austenitizing temperature to over $860{ }^{\circ} \mathrm{C}$ resulted in the yield stress and the fracture stress at about 1230 and $1500 \mathrm{MPa}$, respectively. The highest fracture stress of the experimental steel was found to be $1919 \mathrm{MPa}$ when austenitized at $840{ }^{\circ} \mathrm{C}$. The tensile elongation of the carburized specimens was lower than $3.0 \%$, indicating an early brittle fracture. Clearly, this was because the carburized case is high-carbon martensite with high brittleness. However, clear yield phenomena could be found for all the carburized specimens, as shown in Figure 6.

Table 3. The tensile properties of the carburized specimens of the experimental steel.

\begin{tabular}{cccc}
\hline $\begin{array}{c}\text { Austenitizing Temperature } \\
\left({ }^{\circ} \mathbf{C}\right)\end{array}$ & $\begin{array}{c}\text { Yield Stress } \\
(\mathbf{M P a})\end{array}$ & $\begin{array}{c}\text { Fracture Stress } \\
(\mathbf{M P a})\end{array}$ & $\begin{array}{c}\text { Tensile Elongation } \\
(\mathbf{\%})\end{array}$ \\
\hline 820 & 1322 & 1713 & 1.7 \\
840 & 1249 & 1919 & 3.0 \\
860 & 1227 & 1552 & 1.4 \\
880 & 1231 & 1519 & 1.4 \\
900 & 1244 & 1476 & 1.2 \\
\hline
\end{tabular}

Pavlina and Tyne studied the correlation of tensile strength with hardness for steels [21]. According to their results, the average fracture stresses in the near-surface carburized case and in the transitional region of the experimental steel were calculated to be 2812 and $2170 \mathrm{MPa}$, respectively, which were independent of the austenitizing temperature. Those in the core matrix were calculated to be 1095 and $1524 \mathrm{MPa}$ for the specimens austenitized at $820^{\circ} \mathrm{C}$ and other temperatures, respectively. Since carburized specimens were multilayered, the tensile fracture stresses of carburized specimens would depend on the tensile 
fracture stresses of each layer. Assuming that the tensile fracture stresses of carburized specimens could be estimated through multi-layer stresses weighted by cross sectional area, the calculated results were 1830 and $1932 \mathrm{MPa}$ for the specimens austenitized at $820^{\circ} \mathrm{C}$ and other temperatures, respectively. Compared with the results listed in Table 3, the calculated tensile fracture stresses were not in agreement with the experimental results, indicative of a large error.

Figure 7 shows the calculated true stress-true strain curves of the carburized case and the core and the overall specimen, which was obtained in combination with the carburized case, the transition area, and the core. It is assumed that there exists an Ramber-Osgood relation between the stress and the strain for the carburized case, the transition area, and the core [22]. The calculated overall curve is in good agreement with the experimental one, especially at the low strain stage. Thus, the tensile stress-strain behavior of the carburized specimens depended on both the carburized case and the core. For the experimental steel, the tensile stress-strain behavior did not vary with the austenitizing temperature, due to the similar in-depth hardness distribution.

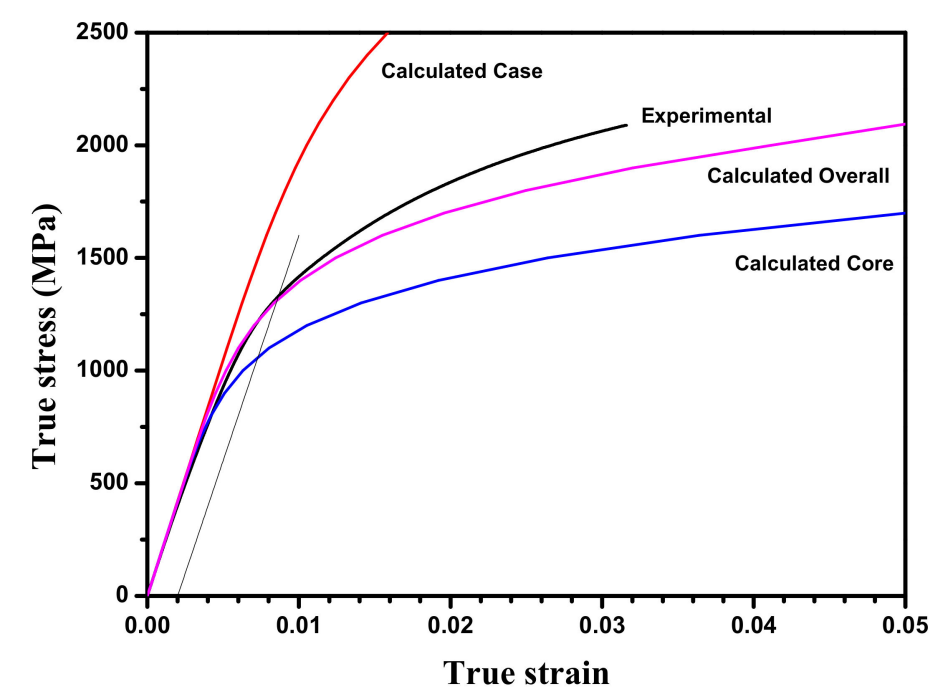

Figure 7. Comparison of the experimental and calculated true stress-true strain curves of the case, the core, and the overall specimens austenitized at different temperatures.

\subsection{Fractography}

The fracture stresses were dependent on the austenitizing temperature, which could be attributed to the occurrence of fractures. It can be seen from Figure 8 that fracture occurred at a relatively early stage with the increase in the austenitizing temperature. The fracture surfaces of the tensile specimens were observed using SEM with the emphasis on the crack initiation sites. As shown in Figure 8, the crack initiation sites were located in the nearsurface region, being about $0.1-0.3 \mathrm{~mm}$ from the surface. Higher magnification micrographs show that the crack initiation sites had a primarily intergranular fracture appearance.

This can be attributed to the high carbon content in the carburized case, which might cause brittleness $[9,11,12]$. Transgranular facets were also observed at the crack initiation sites, which could be related to retained austenite in the carburized case $[7,10,13]$. Compared with the specimens austenitized at $820^{\circ} \mathrm{C}$, the specimens austenitized at other temperatures appeared to be more brittle, with secondary cracks observed, as shown in Figure $8 \mathrm{c}$. It was not clear whether the secondary cracks were formed during quenching or tensile loading. In this specimen, the crack initiation site was just below the surface. Thus, an early failure occurred for the specimens austenitized at over $860^{\circ} \mathrm{C}$, resulting in the lower fracture stresses. The fine microstructure and relatively low content of the retained austenite of $18 \%$ in the specimen austenitized at $820{ }^{\circ} \mathrm{C}$ could be the reason for its high fracture stress. 


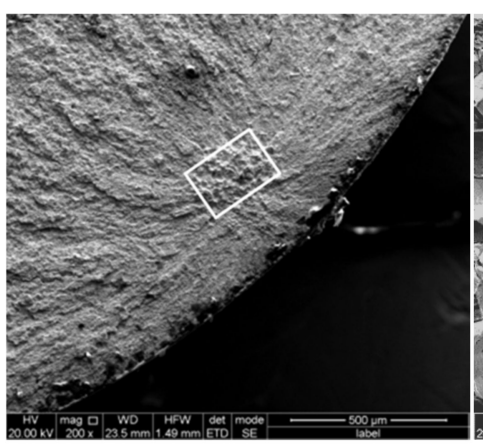

(a)

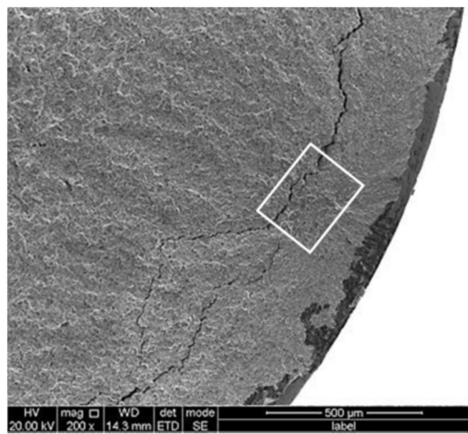

(b)

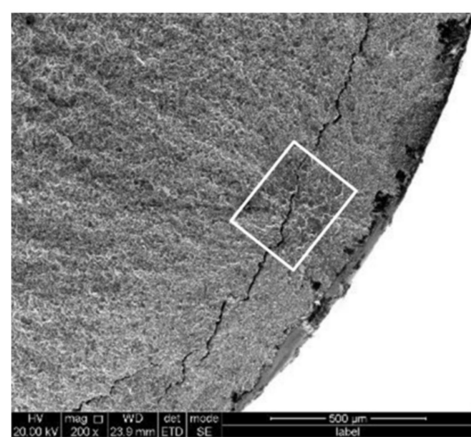

(c)

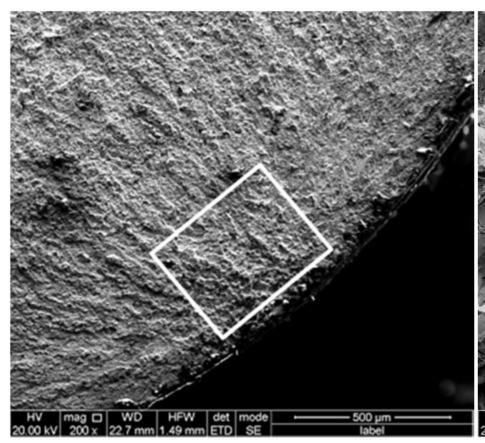

(d)

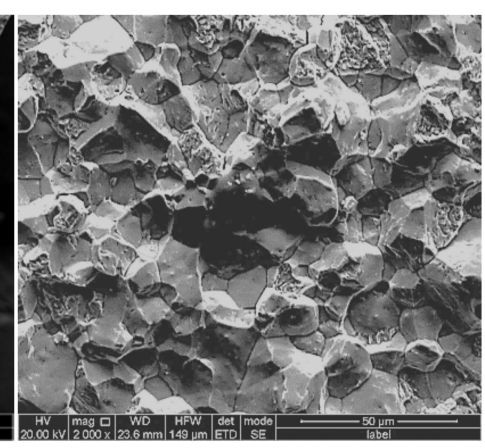

(f)

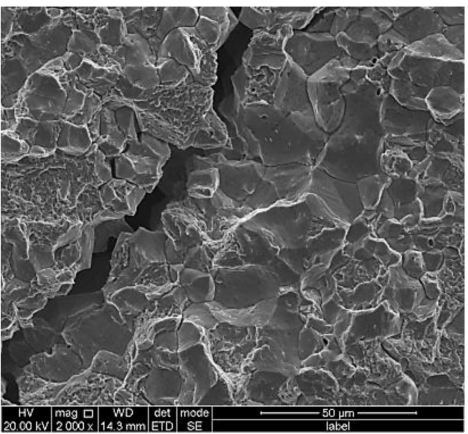

(g)

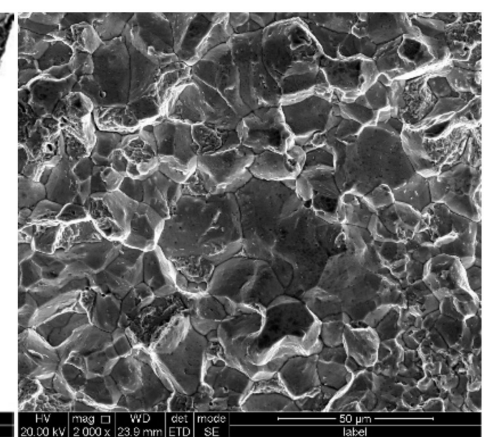

(h)

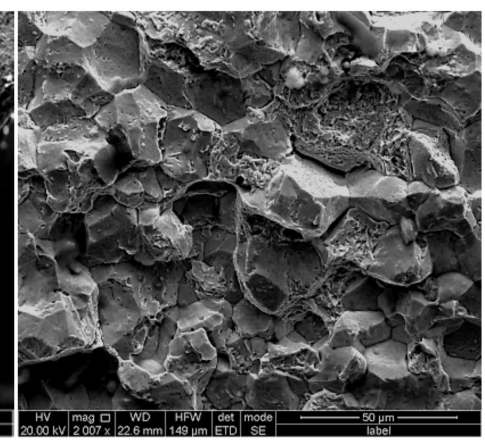

(i)

Figure 8. Cont. 


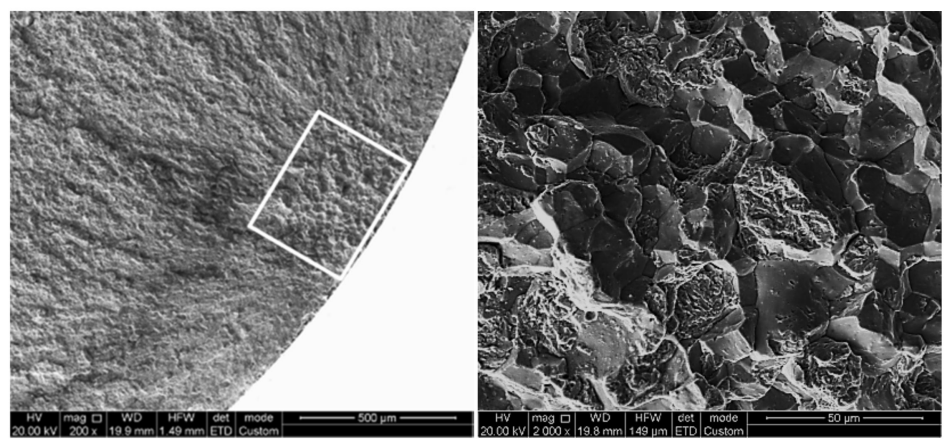

(e)

(j)

Figure 8. SEM fractographs showing (a-e) low-magnification overviews, and $(\mathbf{f}-\mathbf{j})$ crack initiation sites of fracture surfaces of the specimens austenitized at different temperatures of $(\mathbf{a}, \mathbf{f}) 820{ }^{\circ} \mathrm{C}$, $(\mathbf{b}, \mathbf{g}) 840{ }^{\circ} \mathrm{C},(\mathbf{c}, \mathbf{h}) 860^{\circ} \mathrm{C},(\mathbf{d}, \mathbf{i}) 880^{\circ} \mathrm{C}$, and $(\mathbf{e}, \mathbf{j}) 900^{\circ} \mathrm{C}$.

The features of intergranular fracture at the crack initiation site are listed in Table 4. The crack initiation site moved toward the case surface and the intergranular area increased with the increase in the austenitizing temperature. This indicates that the coarser the austenite grain size, the more brittle the grain strength during tensile tests, resulting in early premature fractures. As also listed in Table 4, the estimated carbon content at the crack initiation site was around $0.8 \%$, indicative of high carbon plate martensite with brittleness.

Table 4. Feature of the crack initiation site for the carburized specimens.

\begin{tabular}{cccc}
\hline $\begin{array}{c}\text { Austenitizing Temperature } \\
\left({ }^{\circ} \mathbf{C}\right)\end{array}$ & $\begin{array}{c}\text { Distance of Crack Initiation } \\
\text { Site from Surface } \\
(\mathbf{m m})\end{array}$ & $\begin{array}{c}\text { Area of Intergranular } \\
\text { Fracture } \\
\left(\mathbf{m m}^{\mathbf{2}}\right)\end{array}$ & $\begin{array}{c}\text { Carbon Content at Crack } \\
\text { Initiation Site } \\
\mathbf{( \% )}\end{array}$ \\
\hline 820 & 0.32 & 0.034 & 0.90 \\
840 & 0.29 & 0.062 & 0.82 \\
860 & 0.24 & 0.067 & 0.82 \\
880 & 0.17 & 0.121 & 0.82 \\
900 & 0.15 & 0.129 & 0.80 \\
\hline
\end{tabular}

The fracture stress decreased with the increase in the crack length, in line with Griffith theory [23] as follows:

$$
\sigma_{\mathrm{c}}=\sqrt{\frac{2 E \gamma}{\pi a}}
$$

where $\sigma_{\mathrm{C}}$ is the fracture stress, $E$ is the elasticity modulus, $\gamma$ is the surface energy, and $a$ is the crack length. Since an intergranular fracture mode was found at the crack initiation sites, the crack length could be related to the prior austenite grain size. The lower the austenitizing temperature, the finer the prior austenite grain size. Thus, a decreasing trend of fracture stress with the increase in austenitizing temperature can be expected.

\subsection{Transformation of Retained Austenite}

There was a high content of retained austenite in the carburized case, which can transform into martensite during tensile stress. A study reported that the fraction of retained austenite transformed into martensite depended on the extent of the plastic strain, which can be described as follows [24]:

$$
f_{\gamma}=f_{0} \exp (-k \varepsilon)
$$

where $f_{0}$ and $f_{\gamma}$ are the contents of the retained austenite at the initial time or time, respectively, $\varepsilon$ is the deformation strain, and $k$ is a constant indicating the mechanical stability of the retained austenite where the value of 34 is assumed. The calculated results of 
the retained austenite after fracture of the specimens austenitized at different temperatures are listed in Table 5. Increasing the austenitizing temperature might result in a relatively high content of retained austenite after the fracture, indicative of an early fracture. The highest fracture stress of the specimen austenitized at $840{ }^{\circ} \mathrm{C}$ could be related to its high transformation percentage of $16 \%$ in the retained austenite, as shown in Table 5.

Table 5. Retained austenite fraction of the carburized specimens of the experimental steel during tensile test.

\begin{tabular}{ccc}
\hline $\begin{array}{c}\text { Austenitizing Temperature } \\
\left({ }^{\circ} \mathbf{C}\right)\end{array}$ & $\begin{array}{c}\text { Initial Retained Austenite } \\
\text { Fraction } \\
f_{\mathbf{0}}(\mathbf{\%})\end{array}$ & $\begin{array}{c}\text { Retained Austenite Fraction } \\
\text { after Fracture } \\
f_{\boldsymbol{\gamma}}(\%)\end{array}$ \\
\hline 820 & 18 & 10 \\
840 & 25 & 9 \\
860 & 30 & 19 \\
880 & 23 & 14 \\
900 & 21 & 14 \\
\hline
\end{tabular}

The transformation of the retained austenite in the carburized case into martensite after the tensile tests was proven by the measured results of the retained austenite. As an example, Figure 9 shows the XRD patterns for the carburized case of the specimens austenitized at $900{ }^{\circ} \mathrm{C}$ before and after the tensile tests. The heights of the austenite peaks relative to the heights of the martensite peaks decreased after the tensile test, indicating the transformation of the retained austenite into martensite of about $7 \%$ from $21 \%$ to $14 \%$.

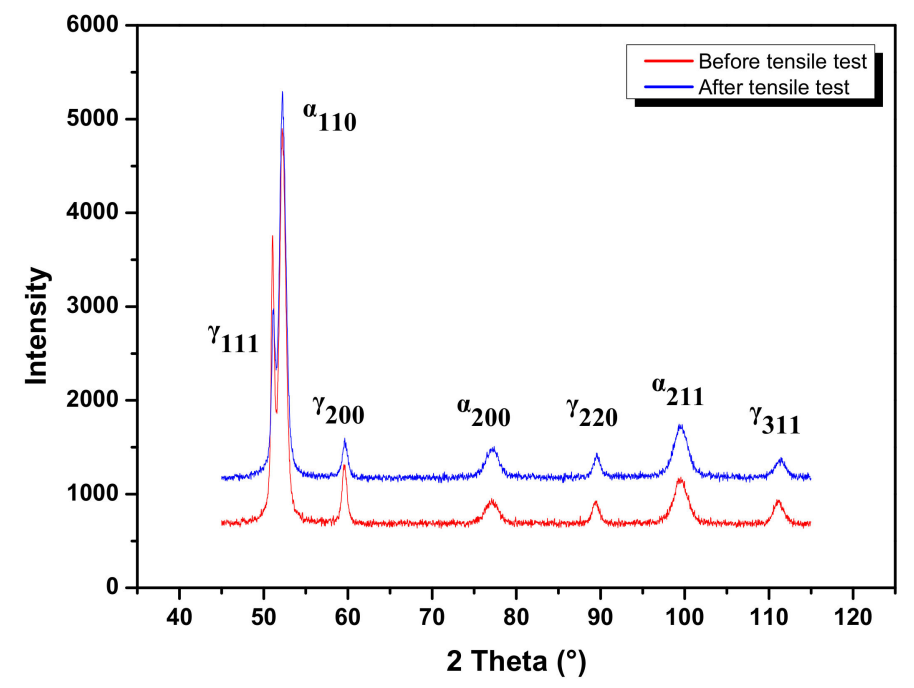

Figure 9. The $\mathrm{X}$-ray diffraction $(\mathrm{XRD})$ patterns for the carburized case of the specimens austenitized at $900{ }^{\circ} \mathrm{C}$ before and after the tensile tests.

Figure 10 shows the Vickers hardness distribution for the carburized case of the specimens austenitized at $900{ }^{\circ} \mathrm{C}$ before and after the tensile tests. The transformation of the retained austenite might result in an increase in hardness, which could contribute to the high fracture stress of the experimental steel compared with the references [6-12]. 


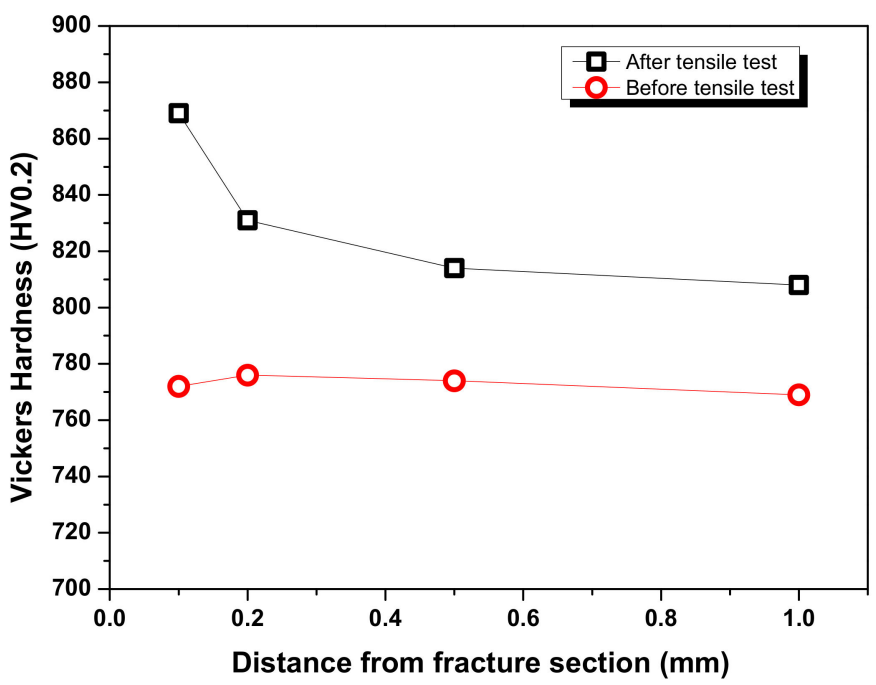

Figure 10. The Vickers hardness distribution for the carburized case of the specimens austenitized at $900{ }^{\circ} \mathrm{C}$ before and after the tensile tests.

\section{Conclusions}

We investigated the microstructure, hardness, and tensile properties of case-hardening gear steel after vacuum carburization and re-austenitization at $820-900{ }^{\circ} \mathrm{C}$, followed by oil quenching and tempering. The following conclusions can be drawn.

(1) The content of retained austenite in the carburized case of the specimens of the experimental steel was measured to be $18-30 \%$, which was dependent on the austenitizing temperature. This is related to the carburized carbon content and the carbide dissolution at the austenitizing temperature.

(2) The tensile stress-strain curves of carburized specimens of the experimental steel showed a similar work hardening exponent of 0.4 and did not vary with the austenitizing temperature. The stress-strain curves were described by considering the carburized case and the core in combination.

(3) Although the case hardness of $800 \mathrm{HV}_{0.2}$ and the carburized depth of $1.2 \mathrm{~mm}$ were similar, the fracture stresses of the carburized specimens showed a decreasing trend with the increasing austenitizing temperatures. Observations of fracture surfaces indicated that cracks initiated at the near-surface carburized case and propagated first in an intergranular mode. The high fracture stress of the $840{ }^{\circ} \mathrm{C}$ austenitized specimen was related to the fine microstructure and high percentage of retained austenite transformed into martensite during the tensile tests.

(4) The optimum austenitizing temperature for the experimental steel was determined to be around $840{ }^{\circ} \mathrm{C}$ when the fracture stress could be expected to be as high as $1900 \mathrm{MPa}$.

Author Contributions: Conceptualization, X.H.; formal analysis, W.C. and M.W.; investigation, W.C. and W.Y.; data calculation, X.H.; writing-original draft preparation, W.C.; writing-review and editing, M.W.; visualization and project administration, K.Y. All authors have read and agreed to the published version of the manuscript.

Funding: National Key Research and Development Program of China (2016YFB0300102).

Acknowledgments: Everyone who contributed to the article has been included among the authors.

Conflicts of Interest: The authors declare no conflict of interest. 


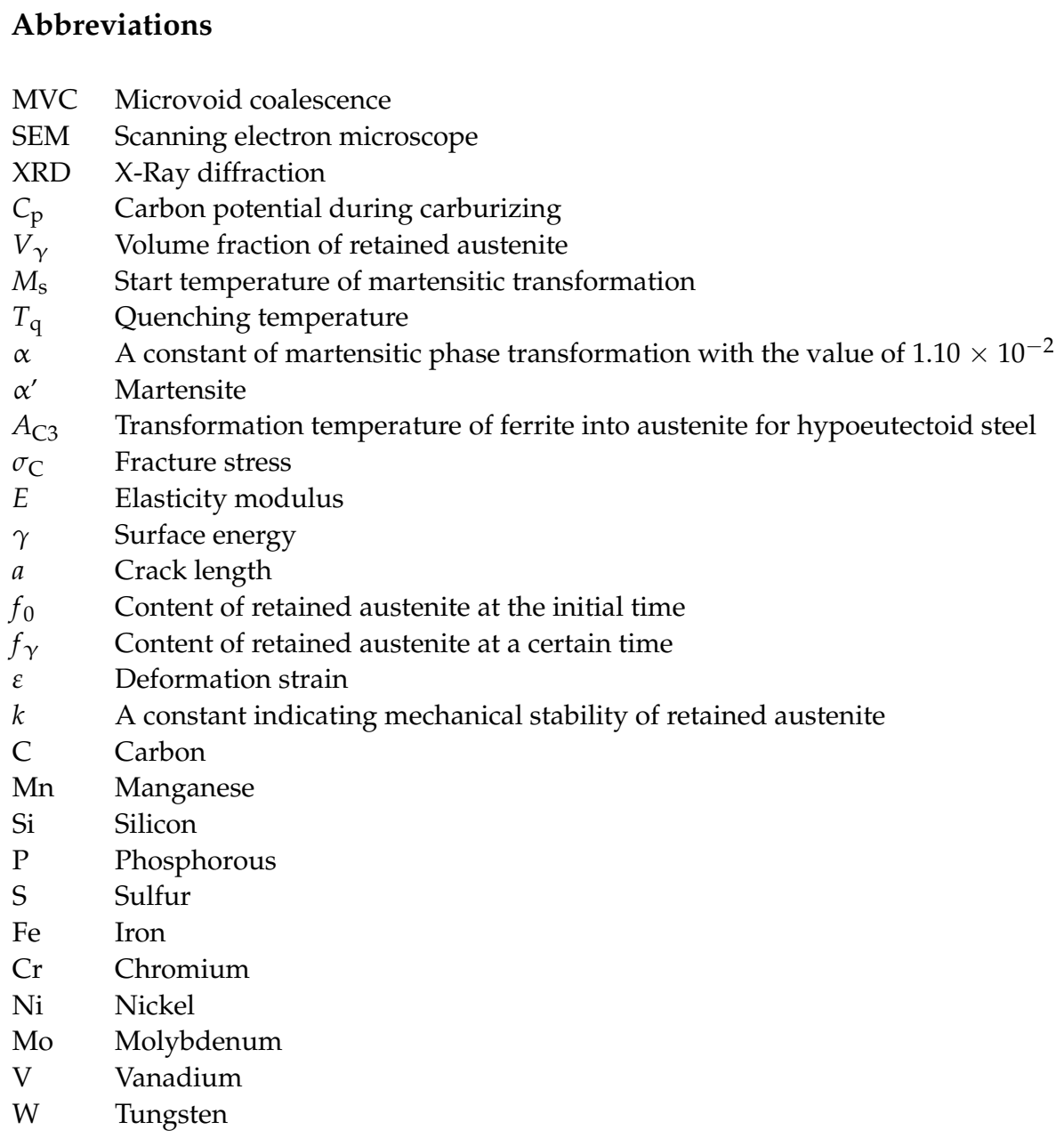

\section{References}

1. Parrish, G. Carburizing: Microstructures and Properties; ASM International: Geauga, OH, USA, 1999.

2. Seo, E.J.; Speer, J.G.; Matlock, D.K.; Cryderman, R.L. Effect of Mo in combination of Nb on austenite grain size control in vacuum carburizing steels. J. Mater. Eng. Perform. 2020, 29, 3575-3584. [CrossRef]

3. Henry, E.C.; O'Brien, C.; Yeddu, H.K. Multi-length scale modeling of carburization, martensitic microstructure evolution and fatigue properties of steel gears. J. Mater. Sci. Technol. 2020, 49, 157-165.

4. $\quad$ Ma, L.; Wang, M.Q.; Shi, J.; Hui, W.J.; Dong, H. Influence of niobium microalloying on fatigue properties of case hardening steels. Mater. Sci. Eng. A 2008, A498, 258-265. [CrossRef]

5. Liu, Y.; Wang, M.Q.; Shi, J.; Hui, W.J.; Fan, G.; Dong, H. Fatigue properties of two case hardening steels after carburization. Int. J. Fatigue 2009, 31, 292-299. [CrossRef]

6. Luther, R.G.; Williams, T.R.G. The tensile properties of carburized and uncarburized low carbon mild steel. J. Mater. Sci. 1974, 9, 136-144. [CrossRef]

7. Krauss, G. The microstructure and fracture of a carburized steel. Metall. Mater. Trans. A 1978, 9, 1527-1535. [CrossRef]

8. Furukawa, T.; Konuma, S.; Sakaniwa, H. Effects of chemical composition and heat treatment on mechanical properties of carburized steels. Tetsu Hagane 1979, 65, 1204-1212. [CrossRef]

9. Li, F.Z.; Li, C.Z. The influence of heat treatment after carburizing and retained austenite in the carburized layer on the strength and toughness of steel. Trans. Heat Treat. Met. 1985, 6, 59-68.

10. Erdogan, M.; Tekeli, S. The effect of martensite volume fraction and particle size on the tensile properties of a surface-carburized AISI 8620 steel with a dual-phase core microstructure. Mater. Charact. 2003, 49, 445-454. [CrossRef]

11. Murai, N. Intergranular fracture of carburized steel. In Mechanical Behavior of Materials VI; Pergamon: Kyoto, Japan, 1992. [CrossRef]

12. Yu, E.J.; Jung, H.J.; Kim, K.S.; Kim, E.J.; Kim, J.Y. Influence of carbide formation on tensile and fatigue properties of carburized steels. Appl. Microsc. 2013, 43, 81-87. [CrossRef]

13. Farivar, H.; Deepu, M.J.; Hans, M.; Phanikumar, G.; Bleck, W.; Prahl, U. Influence of post-carburizing heat treatment on the core microstructural evolution and the resulting mechanical properties in case-hardened steel components. Mater. Sci. Eng. A 2019, 744, 778-789. [CrossRef] 
14. Neu, R.W.; Sehitoglu, H. Stress-induced transformation in a carburized steel-Experiments and analysis. Acta Metall. Mater. 1992, 40, 2257-2268. [CrossRef]

15. Silva, V.F.; Canale, L.F.; Spinelli, D.; Bose-Filho, W.W.; Crnkovic, O.R. Influence of retained austenite on short fatigue crack growth and wear resistance of case carburized steel. J. Mater. Eng. Perform. 1999, 8, 543-548. [CrossRef]

16. Roy, S.; Sundararajan, S. The effect of heat treatment routes on the retained austenite and tribomechanical properties of carburized AISI 8620 steel. Surf. Coat. Technol. 2016, 308, 236-243. [CrossRef]

17. Benselya, A.; Senthilkumara, D.; Mohan, L.D.; Nagarajana, G.; Rajaduraib, A. Effect of cryogenic treatment on tensile behavior of case carburized steel-815M17. Mater. Charact. 2007, 58, 485-491. [CrossRef]

18. Baldissera, P.; Delprete, C. Effects of deep cryogenic treatment on static mechanical properties of $18 \mathrm{NiCrMo5}$ carburized steel. Mater. Des. 2009, 30, 1435-1440. [CrossRef]

19. Magee, C.L. Phase Transformation; ASM: Geauga, OH, USA, 1970; p. 115.

20. Brooks, C.R. Principles of the Heat Treatment of Plain and Low Alloy Steels; ASM International: Geauga, OH, USA, $1996 ;$ p. 307.

21. Pavlina, E.J.; Van Tyne, C.J. Correlation of yield strength and tensile strength with hardness for steels. J. Mater. Eng. Perform. 2008, 17, 888-893. [CrossRef]

22. Cular, I.; Vuckovic, K.; Zezelj, D.; Glodez, S. Analytical approach for low and high cycle bending fatigue life prediction of carburized gear steel specimens. Eng. Fail. Anal. 2020, 108, 104328. [CrossRef]

23. Griffth, A.A. Phenomenon of rupture and flow in solids. Philos. Trans. R. Soc. Lond. 1921, A221, 163-198.

24. Sugimoto, K.; Yu, B.; Mukai, Y.; Ikeda, S. Microstructure and formability of aluminum bearing TRIP-aided steels with annealed martensite matrix. ISIJ Int. 2005, 45, 1194-1200. [CrossRef] 